\title{
Workplace innovation: European policy and theoretical foundation
}

ARTICLE in WORLD REVIEW OF ENTREPRENEURSHIP MANAGEMENT AND SUSTAINABLE DEVELOPMENT . JANUARY 2016

DOI: $10.1504 /$ WREMSD. 2016.073428

READS

21

3 AUTHORS:

Frank Pot

Radboud University Nijmegen

43 PUBLICATIONS 132 CITATIONS

SEE PROFILE

\section{Steven Dhondt}

TNO

79 PUBLICATIONS 103 CITATIONS

SEE PROFILE
Peter Totterdill

Kingston University London

34 PUBLICATIONS 27 CITATIONS

SEE PROFILE 


\title{
Workplace innovation: European policy and theoretical foundation
}

\section{Frank Pot*}

TNO, Netherlands Organisation for Applied Scientific Research, Radboud University Nijmegen,

Fagelstraat 46, 2334 AZ Leiden, The Netherlands

Email: frank.pot@ardan.demon.nl

*Corresponding author

\section{Peter Totterdill}

UK Work Organisation Network, 54 High Pavement, Nottingham NG1 1HW, UK and

Kingston University,

River House, 53-57 High Street,

Kingston upon Thames,

Surrey KT1 1LQ, UK

and

University of Bath,

Claverton Down, Bath, BA2 7AY, UK

Email: peter.totterdill@ukwon.net

\section{Steven Dhondt}

TNO, Netherlands Organisation for Applied Scientific Research, P.O. Box 3005, 2301 DA Leiden, The Netherlands

and

Catholic University of Leuven,

Parkstraat 45, Bus 3601,

3000, Leuven, Belgium

Email: steven.dhondt@tno.nl

\begin{abstract}
Workplace innovation is gaining profile as an emerging European policy, creating organisational performance and quality jobs. DG GROW and DG EMPL are leading. Policies regarding work organisation and workplace innovation in the EU over the last 20 years used to be rather fragmented, but more coherence is likely to develop in the near future. Besides social partners and government- and EU-officials a major role was played by European Networks of Applied Researchers. They provided the theories that are part of the foundation of such policies. The evidence for the positive effects of workplace innovation stimulated many entrepreneurs and managers to apply it. National programs appear to be helpful, in particular where coalitions of employers' associations, trade unions, governments and research institutes exist. However, this is still a minority. More research is needed into the obstacles and the mechanism to promote implementation.
\end{abstract}


Keywords: work organisation; organisational innovation; European policy; theoretical foundation; workplace innovation.

Reference to this paper should be made as follows: Pot, F., Totterdill, P. and Dhondt, S. (2016) 'Workplace innovation: European policy and theoretical foundation', World Review of Entrepreneurship, Management and Sustainable Development, Vol. 12, No. 1, pp.13-32.

Biographical notes: Frank Pot is Emeritus Professor of Social Innovation of Work and Employment, Institute for Management Research at the Radboud University Nijmegen, the Netherlands. He is the Chair of the Advisory Board of the European Workplace Innovation Network (EUWIN, 2013-2016) and a member of the Scientific Advisory Board of Social Innovation: Driver for Change (SI-DRIVE, 2014-2018). He publishes scientific and policy articles and is an invited expert for European organisations. He has been working at TNO in the Netherlands for almost 25 years and used to be the Director of the Institute TNO Work and Employment. In the ' 90 s, he was a part-time Professor of Work and Technology at the Leiden University, the Netherlands.

Peter Totterdill is the Chief Executive of the UK Work Organisation Network (UKWON), a not-for-profit organisation collaborating with employers' organisations, trade unions, professional bodies, public agencies and universities committed to developing and disseminating new ways of working. $\mathrm{He}$ is also the Director of UKWONs sister company Workplace Innovation Limited. See http://www.goodworkplaces.net. A passionate advocate of organisational practices that combine high performance and high quality of working life, his career as a researcher, policy advisor and consultant has focused on building bridges between academic knowledge and practice. He maintains close academic links with universities across the UK and Europe, and especially through his role as a Visiting Professor at the Kingston University London and a Senior Research Fellow at the University of Bath.

Steven Dhondt is a Visiting Professor of Social Innovation at the University of Leuven and a Senior Research Scientist at TNO. He is active in building a sound theoretical foundation for workplace innovation and why companies do invest in such practices. His work encompasses theoretical accounts, major surveys and building of methods for Dutch, Belgian and EU-customers. Over the past years, as a coordinator of the European Learning Network for Workplace Innovation, he has built an extensive European network of practitioners, social partners and knowledge partners for the European Commission.

This paper is a revised and expanded version of a paper entitled 'Development of the concept of workplace innovation in European policy and its theoretical foundation' presented at Seminar 'Current Scientific Work on Workplace Innovation', EUWIN/Kozminski University, Warsaw, 16 June 2015.

\section{Introduction}

Workplace innovation is gaining profile as an emerging European policy, creating organisational performance and quality jobs. Workplace innovation is first of all a policy concept. In the application for the European Workplace Innovation Network (EUWIN) that started in 2013 workplace innovation is described as follows: "Workplace 
innovations designate new and combined interventions in work organisation, human resource management, labour relations and supportive technologies. It is important to recognise both process and outcomes. The term workplace innovation describes the participatory and inclusive nature of innovations that embed workplace practices grounded in continuing reflection, learning and improvements in the way in which organisations manage their employees, organise work and deploy technologies. It champions workplace cultures and processes in which productive reflection is a part of everyday working life. It builds bridges between the strategic knowledge of the leadership, the professional and tacit knowledge of frontline employees and the organisational design knowledge of experts. It seeks to engage all stakeholders in dialogue in which the force of the better argument prevails. It works towards "win-win" outcomes in which a creative convergence (rather than a trade-off) is forged between enhanced organisational performance and enhanced quality of working life". The concept refers to the organisational level (workplace as an establishment or - virtual organisation) and not to individual workplaces.

How can this emergence of interest in workplace innovation, this new élan, be understood?

Figure 1 The fifth element (see online version for colours)

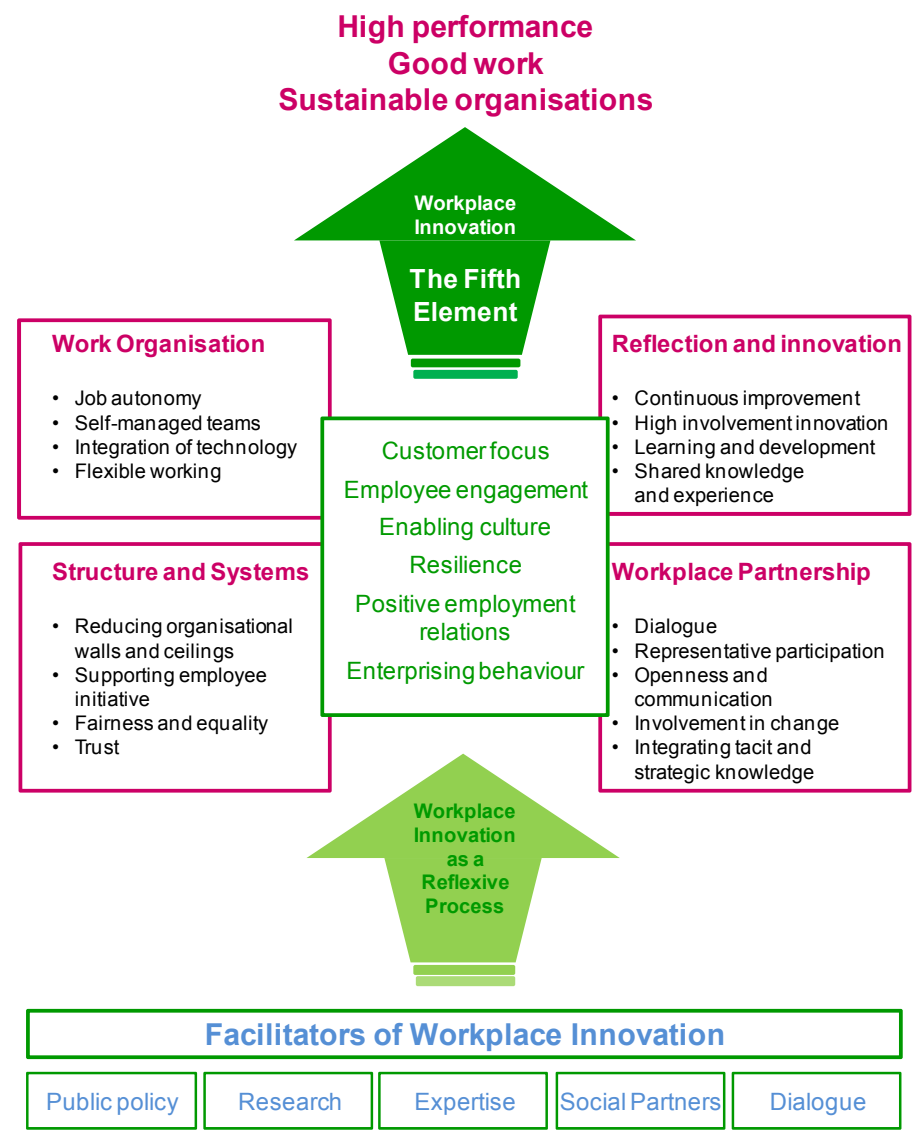


Source: Totterdill (2013)

This paper describes the development of European policies regarding work organisation and workplace innovation over the last 20 years and its societal context. Three periods are being distinguished: the nineties, the Lisbon Agenda and the EU 2020 Strategy. There is quite some evidence for the positive effects of workplace innovation. How can this be understood theoretically? A few of those economic, sociological and psychological theories are presented. In this article, we draw on The Fifth Element concept of EUWIN (Totterdill, 2013) to show the current theoretical inroads to understand the changes and to help develop new theories and methods to support companies. The fifth element refers to the chemistry of integrating four elements: 'work organisation' (first element), 'structures and systems' (second element), 'learning and reflection' (third element) and 'workplace partnership' (fourth element) (Figure 1).

\section{Recent updates of productivity and industrial democracy policies}

Workplace innovation, as it developed from the beginning of this century, is a member of the Sociotechnical Systems Design (STSD)-family (Mohr and Van Amelsvoort, 2015), going back to the restructuring of Europe after the Second World War, starting more or less the same policies for productivity and industrial democracy in several Western European countries.

Although consensus about the use of the concept is growing and its policy profile is getting stronger, different concepts are being used for more or less the same approach (Kesselring et al., 2014). Examples are 'innovative workplaces' (e.g., OECD, 2010a, 2010b; and sometimes EESC, 2011) and 'sustainable work systems' or 'sustainable work' which concepts are still used by the Swedish part of the STSD-family (Docherty et al., 2002). And, as can be expected, in national programs and initiatives (Totterdill et al., 2009; Pot et al., 2012b) concepts in the country's language are being used. 'Workplace innovation' is also being used in the USA, Canada and Australia besides concepts such as 'high involvement workplaces' and 'relational coordination' (Gittell et al., 2010).

\subsection{Urgency}

How can this emergence of interest in workplace innovation, this new élan, be understood? The broader context is that in the early 1990s a significant shift in Europe's economy and businesses could be observed fuelled by information technology. This shift reversed the historical pattern where tangible capital was considered to be the main asset in companies. Around 1990 investments in intangible capital (in percentage of adjusted GNP), such as patents, R\&D, marketing, organisational competences became higher than investments in tangible capital (Corrado and Hulten, 2010). Regarding innovation the conviction grew in Europa that 'social innovation' (work organisation, competence development, employee participation, etc.) is probably more important than 'technological innovation' to explain the company's performance (Bolwijn et al., 1986). Business models changed from products (Philips: light bulbs) to services (Philips: city lighting). This context explains the need to develop and utilise the skills and competences of the present and potential workforce to increase added value as part of a competitive 
and knowledge-based global economy (European Commission, 2014). One more reason for 'workplace innovation' is that private and public organisations can only fully benefit from technological innovation if it is embedded in workplace innovation (making technology work by means of proper organisation). Finally, there is a need to enhance labour productivity to maintain our level of welfare and social security in the near future with fewer people in the workforce due to the ageing population.

\subsection{The '90s, the 'green paper', EWON and the European work and technology consortium}

This growing awareness of the need for new forms of work organisation led to a number of activities on the European level. During the mid-1990s the employment Directorate General (DG EMPL) of the European Commission established ACTEUR, a policy advisory group which brought together representatives from national programs and initiatives as well as officials from other Member States where comparable initiatives were absent. At the same time individual lobbyists mobilised an influential coalition of researchers and policymakers, resulting in the publication in 1995 of 'Europe's next step: organisational innovation, competition and employment', a manifesto for the future of work organisation (Andreasen et al., 1995). Also in 1995, unbeknown to the officials managing ACTEUR, a different part of DG EMPL established the European Work \& Technology Consortium. The Consortium brought together 16 public policy and research organisations from ten Member States to create a 'Medium Term Plan for Collaborative Action for the Modernisation of Work Organisation' (Totterdill, 2003). A seminal moment for those advocating the recognition of workplace innovation as a key dimension in EU strategy came in 1997 with the publication of the Commission's Green Paper 'Partnership for a new organisation of work': "The Green Paper invites the social partners and public authorities to seek to build a partnership for the development of a new framework for the modernisation of work. Such a partnership could make a significant contribution to achieving the objective of a productive, learning and participative organisation of work". Interest in work organisation as a driver for European competitiveness and quality of working life had been growing, partly fuelled by national initiatives such as those in Ireland, France, Germany, the Netherlands and the massive Work Environment Fund which made a significant impact in Sweden during the 1980s and early '90s. The Green Paper is a curiously hybrid document doubtless reflecting internal differences within DG EMPL. According to Ennals the Green Paper combines in essence a legalistic discussion of the regulatory conditions which might help or hinder workplace flexibility visibly stitched together with an open-ended call for measures by governments and social partners to stimulate participative working practices. Nonetheless it provided a rallying point for those who had been advocating recognition of workplace innovation, and there was high expectation that specific policy interventions would follow (Ennals, 1998; Ennals et al., 2004) Based on the responses to this consultative document 'Modernising the organisation of work - A positive approach to change' was published by the European Commission in 1998. A substantial volume of evidence for the positive effects of new forms of work organisation was provided by the European Work \& Technology Consortium (1998). By 1998, it had become clear that, despite enthusiasm from some trade unions, there was little appetite amongst European social partners for intervention in the workplace whether regulatory or otherwise. Likewise 
several Member States and some senior officials within DG EMPL remained not enthusiastic, considering workplace innovation to be no more than a 'Nordic obsession' (Totterdill et al., 2012a).

ACTEUR was re-launched in 1997 as the European Work Organisation Network (EWON) to support the policy of 'a new organisation of work' and instigated a series of policy dialogues, conferences and research projects until 2002, accompanied by a news bulletin. Eurofound conducted a large scale research project into 'employee participation in organisational change' which provided again evidence for the positive relation between employee participation and organisational performance (EPOC: Eurofound, 1997). EWON summarised for DG EMPL the positive research results in different countries (Savage, 2001) and so did other researchers (Brödner and Latniak, 2002). DG Research commissioned research into successful cases. In the report the concept of workplace innovation was used (Totterdill et al., 2002) EWON was discontinued by DG EMPL itself. This was never explained to the participants. Most of the attention for organisational innovation was later assigned to EU OSHA, the European Agency for Safety and Health at Work (related to stress prevention and wellbeing at work) and to Eurofound.

\subsection{The Lisbon agenda and Work-In-Net and EDI}

Not much later, facilitated by the 6th Framework Program ERA-NET the 'Work-In-Net' (WIN) consortium was one of the networks continuing the work of EWON and the European Work \& Technology Consortium from 2004 until 2010 (Alasoini et al., 2005; WIN, 2010), coordinating research in the field of 'Innovation of Work Organisation'. In the same period the Employee-Driven Innovation (EDI) Network was established, in particular by the Norwegian and Danish trade union confederations and researchers in the field of work organisation (Høyrup et al., 2012). This network was connected to the European program 'Lifelong Learning in Europe (LLinE)'. EDI became part of the Norwegian government policy in 2008. A handbook for EDI was made by the trade union confederation (LO) and the Confederation of Norwegian Enterprise (NHO) together.

Since the Lisbon Growth and Jobs Strategy had been launched in 2000, the European Employment Strategy's overarching objectives have encompassed not only full employment, but also the promotion of quality and productivity at work. In the Commission the "design and dissemination of innovative and sustainable forms of work organisation" (European Commission, 2003) continued to be cited as a means of enhancing productivity, responsiveness and quality, as well as improving working life and the retention of older employees. By the middle of the decade, EU policy outputs relevant to the workplace read like a checklist of fashionable ideas of good practice, for example Corporate Social Responsibility, Financial Participation, Anticipating and Managing Change and Work-Related Stress. Each of these policy interventions made a potentially significant contribution in its own right to European economic and social policy objectives, but collectively offered an insufficiently integrated vision of the sustainable workplace (Totterdill et al., 2012a). The renewed Lisbon strategy agreed in March 2005 put growth and jobs at the top of Europe's political priorities and implied fresh commitment to a comprehensive approach. In the 'Guidelines for the employment policies of the Member States' we find the following text in proposed guideline 7: "Work-life balance policies with the provision of affordable care and innovation in work 
organisation should be geared to raising employment rates, particularly among youth, older workers and women, in particular to retain highly-skilled women in scientific and technical fields. Member States should also remove barriers to labour market entry for newcomers, support self-employment and job creation in areas including green employment and care and promote social innovation" [European Commission, (2010b), p.8]. The title of the EU strategy for occupational safety and health (OSH) in this period was: 'Healthy and productive jobs'.

However, according to Totterdill et al. (2012a) 'better organisation of work' remained largely undefined in this policy narrative and its status as a factor 'which should be analysed' is a characteristic Commission obfuscation. There is very little evidence to show that the Integrated Guidelines stimulated action at national level to support new forms of work organisation. Member States such as those in the Nordic Countries, Netherlands, France and Germany with a tradition of policies and programs focused on workplace innovation continued to deliver them; but countries with no such tradition continued, by and large, to ignore the issue (e.g., Greece: Ioannou, 2006).

This was also the case in the "new member states 'of the EU, the former socialist countries. Implementing workplace innovation is even more difficult for them because they have another tradition in which concepts such as productivity, industrial democracy and social dialogue had different meanings than the same concepts in Western Europe. In the eighties the Central and Eastern European countries became familiar with the Japanese style of management and work organisation as most of these countries established productivity centres with Japanese aid funds and Japanese consultants (ex-managers in their 'second career'). These centres were connected to Western European centres through their membership of the European Association of National Productivity Centres (EANPC). The EANPC (2005) promotes not only productivity, but an integrated approach with quality of working life and sustainability. After these countries had entered the European Union the Japanese aid was discontinued. Other exchanges of views on work organisation were organised in the eighties by the European Coordination Centre for Research and Documentation in the Social Sciences ("the Vienna Centre'), a strong network of researchers from East and West (Grootings et al., 1991). The Vienna Centre had been established in the sixties by UNESCO and the International Social Science Council (ISSC).

Even in the Nordic countries implementing workplace innovation was not a matter of course; in Sweden the programs and research were partly discontinued by the new centreright government in 2006 (Sandberg, 2013). The outcome is a European policy pattern that has remained fatally fragmented: a series of separate EU policy fields that add up to less than the sum of the parts.

In 2007, a European Social Fund (ESF)-program (DG EMPL) focused on a more flexible labour market. One of the main areas proposed for investment was the "design and dissemination of innovative and productive methods of work organisation". EWON prepared a report on this subject for the Commission (EWON, 2002). There are instances in Finland, Netherlands, Belgium, Germany and Sweden where it has been used as a foundation for national programs or initiatives. However these examples are generally found in countries with embedded structures and institutions concerned with work organisation. 


\subsection{EU2020 Strategy and EUWIN}

Since the demise of the 1997 Green Paper, workplace innovation has fallen through the gaps between several policy platforms including competitiveness, innovation, employment and social inclusion - even though it has profound implications for each. The formulation of the EUs Europe 2020 vision and strategy during 2009-2010 (European Commission, 2010a) therefore provided an important opportunity for European policymakers to assimilate evidence of how innovation in working practices can address economic and social priorities. However, that opportunity was missed by the policy makers at that time (Dortmund-Brussels Declaration, 2012).

While the broad vision behind Europe 2020 may represent widely acceptable goals, it fell into the same traps as the previous Lisbon strategy. In particular, there was no concrete model of how convergence between quite different policy objectives such as competitiveness, innovation, employment and social inclusion will be achieved in practice.

\subsubsection{A new start}

In March 2011, the European Commission's DG Enterprise \& Industry organised a workshop on workplace innovation within the launch of its Social Innovation Europe initiative (Dhondt et al., 2011; Pot et al., 2012a). This launch reflected a growing recognition that innovation, central to the EUs 2020 economic strategy, has a clear social dimension. Key influences on the European Commission included a 2011 Opinion of the European Economic and Social Committee on 'Innovative workplaces as a source of productivity and quality jobs' (EESC, 2011) and the 'Dortmund-Brussels position Paper' (Dortmund-Brussels Declaration, 2012) signed by more than 30 experts and practitioners across the EU, both calling for more proactive interventions by the European Commission.

In order to define concrete ways to move the policy agenda forward at EU level, the Commission subsequently organised a workshop in Brussels in May 2012 which brought together 50 thought leaders and leading companies in workplace innovation from across Europe. Following discussion at the European Council, the Commission announced funding for a EUWIN embracing all 27 Member States, candidate countries, Switzerland and Norway. The Network was to:

- focus on upscaling through awareness raising and knowledge sharing

- $\quad$ aim to create a critical mass, reducing the current fragmentation across Europe between practitioners, policymakers and researchers concerned with workplace innovation

- emphasise multi-channel communication, including social media, as a means of shaping management awareness.

\subsubsection{DG GROW}

According to DG GROW workplace innovation improves motivation and working conditions for employees, which leads to increased labour productivity, innovation capability, market resilience, and overall business competitiveness. All enterprises, no matter their size, can benefit from workplace innovation. It improves performance and 
working lives, and encourages creativity of employees through positive organisational changes, combines leadership with hands-on, practical knowledge of frontline employees and engages all stakeholders in the process of change.

The main objectives of the DG GROW initiative are to foster the uptake of workplace innovation across European businesses and raise policy maker awareness, at all levels, of the benefits of these innovations (http://ec.europa.eu/growth/industry/innovation/policy/ workplace/index_en.htm).

Through DG GROW, the European Commission prioritised workplace innovation with, for example, the reinforced 2020 EU Industrial Policy Communication and the innovation policy. Crucially it established the EUWIN - EUWIN in 2013 to support this priority, to exchange good practices and establish 'workplace innovation alliances' of employers, trade unions, governments and knowledge institutes.

This policy is also part of the 'Advanced Manufacturing Programme': (ADMA). It is said that "Workplace innovation has to provide advanced solutions for manufacturing industry, based on the newest technologies. Virtual reality and side laboratories, where employees can perform extra research and experimentation, not connected with their daily tasks, are examples of combining advanced manufacturing technologies and advanced workplaces. Furthermore, workplace innovation can help companies to enhance competitiveness by using the innovativeness and creativity of all employees. (...) The Commission has included workplace innovation aspects in the R\&D\&I programs for advanced manufacturing. Explicitly including R\&D on human-centred manufacturing could enhance the active and innovative role of people in factories and could contribute to design the workplaces of the future" (European Commission, 2014).

\subsubsection{DG EMPL}

Eurofound organised the first seminar on workplace innovation in 2005 and developed the concept over the years in the European Working Conditions Survey (EWCS; Eurofound, 2012) and the European Company Survey (ECS; Eurofound, 2013). In 2010, a workshop was organised by DG EMPL and some researchers to explore the concept of workplace innovation again (Totterdill, 2010). Since the launch of Social Innovation Europe in 2011 'social innovation of work and employment' became a topic in policies of DG ENTR (Enterprise and Industry, now DG GROW) as well as DG EMPL. "With the Europe 2020 Strategy it also became a priority to support workplace innovation aimed at improving staff motivation and working conditions with a view to enhancing the EUs innovation capability, labour productivity and organisational performance" [European Commission, (2015), pp.169-70].

EU-OSHA commissioned a literature review on the relation between workplace innovation and OSH (Eeckelaert et al., 2012) because the claim of workplace innovation is to improve quality of working life and organisational performance simultaneously. Consequently workplace innovation was connected to 'wellbeing at work' in the research priorities of OSH (EU-OSHA, 2013a) as well as in the policy to extend OSH to 'wellbeing at work' (EU-OSHA, 2013b). In the biannual conferences of the European Partnership for Research on OSH (PEROSH) on wellbeing at work 'workplace innovation' became a separate track (Manchester 2012; Copenhagen 2014, Amsterdam 2016).

In 2015, DG EMPL published 'Employment and social developments in Europe 2014'. Chapter 3 is about 'the future of work in Europe: job quality and work 
organisation for a smart, sustainable and inclusive growth". One of the paragraph titles is "Complementing technological innovation with workplace innovation". Presenting much empirical research - among which are Eurofound's European Working Conditions Surveys - its conclusion is that "Better jobs and work organisation yield a more productive workforce". Having better jobs and work organisation reduces the risk of stress, enhances wellbeing and leads to a lower tendency to quit the job. Better work organisation implies in particular a balance between job demands (job intensity) and job control (job autonomy), wholeness of tasks and more open access to decision-making processes. These are a few of the indicators which, the report suggests, should inform EU policy making.

Other topics in this chapter are wages, OSH, and work-life and gender balance. It explores the ways in which technological change and innovation will transform the job landscape of the future (polarisation) and can lead to a possible industrial renaissance in the EU. In this context managing the transition into a new labour market where many jobs succumb to automation must become a key priority for policymakers, according to DG EMPL.

The chapter then explores how work organisation can be shaped to increase productivity and labour market participation under the continuous pressure of ongoing structural changes (technological progress, globalisation, demographic change and the greening of the economy). It looks at how stimulating creativity and fostering exchanges between workers can prevent stress and help maintain good physical and mental health, while at the same time improving productivity and innovation capacity. It sees how special arrangements can be implemented to accommodate older workers, workers with disabilities or certain diseases, and workers with family responsibilities. The section then discusses future challenges with respect to workplace learning. It ends by examining how expanding global value chains will affect work organisation, focusing on risks related to the global restructuring of value chains, virtual collaboration across time zones and the absence of multi-layered social dialogue.

One of the conclusions is that for the knowledge-based potential to materialise, the knowledge triangle (knowledge, education, innovation) has to be complemented by forms of work organisation that use workers' human capital to their fullest. It will be important actively to engage employees in identifying and developing solutions while allowing them to participate in the implementation of work innovations so that they become more receptive to change.

"In this context, an important policy would be to facilitate the creation of EU-wide platforms that allow employees and employers to exchange experiences in developing and implementing solutions related to production and work organisation. The specific characteristics of such platforms will vary between production entities and may take place at European or national level. They can promote the exchange of experiences, help identify best practices, monitor their implementation, assess their impact on productivity and identify social implications" [European Commission, (2015), p.163].

The proposal to facilitate the creation of EU-wide platforms looks very similar to the EUWIN (2013-2016) which was commissioned by DG ENTR.

In the meantime the concept of workplace innovation gained policy profile. It was also used by the European Parliament (2013) and IndustriAll European Trade Union (IndustriAll European Trade Union, 2014) in their programs for an industrial renaissance as well as in national initiatives in Ireland and the UK and in the translations of national 
programs in Finland, Netherlands, Germany, Flanders/Belgium and Basque Country/Spain.

\subsubsection{An emerging European policy}

As shown in the previous section, the policies of DG EMPL and DG GROW concerning workplace innovation have many topics in common. So an integrated European policy could arise. This could include DG Regions because workplace innovation alliances can play a major role in regional development as well as DG Research to support and improve these policies by research. So far in the EU2020 programs little attention is paid to research. Although Eurofound has strengthened workplace innovation in its surveys and EU-OSHA has put the subject in the list of research priorities, only a few new research opportunities have been created, so far in the context of 'advanced manufacturing' and 'social innovation'.

\section{Theories supporting workplace innovation}

Well, as said before workplace innovation is an urgent matter and it promises better organisational performance and better jobs. There is lots of evidence for the credibility of this promise, already in the nineties as described, but also from recent research (Ramstad, 2009; Gittell et al., 2010; Pot, 2011; Pot et al., 2012a, 2012b; Totterdill et al., 2012a, 2012b; Oeij et al., 2015). The next question is "how can be understood that workplace innovation works? Which theoretical foundations are applicable?" As said in the introduction, we draw on The Fifth Element concept of EUWIN (Totterdill, 2013) to show the current theoretical inroads to understand the changes and to help develop new theories and methods to support companies. The fifth element refers to the chemistry of integrating four elements: 'work organisation' (first element), 'structures and systems' (second element), 'learning and reflection' (third element) and 'workplace partnership' (fourth element) (Figure 1).

\subsection{The first and second element: job design, work organisation, structures and systems}

A first important theoretical source for workplace innovation is the Dutch sociologist, Ulbo De Sitter. In De Sitter's STSD theory the central idea is the balance between 'control requirements' (quantitative and qualitative demands) and 'control capacity' (job control). "It's not the problems and disturbances in the work that cause stress, but the hindrances to solve them" [De Sitter, (1981), p.155]. In order to maintain this balance, control capacity is required regarding the performance of a given job on individual job level (internal control capacity) as well as regarding the division of labour on production group and plant level (external control capacity): "from complex organisations with simple jobs to simple organisations with complex jobs" (De Sitter et al., 1997). So, besides internal control capacity, complex jobs also include participation in external control activities on production group and plant level (shop floor consultation on processes, division of labour, targets, etc.). The aim of this sociotechnical design is to simultaneously result in improved organisational performance, quality of working life and better labour relations. 
The concept of complex jobs can also be found in two other theories: the action regulation theory - although in the wording of 'complete jobs' - which was developed by Hacker (2003) and Volpert et al. (1989) and the double loop learning theory by Argyris and Schön (1978; see next paragraph The third element). Hacker's “Action theory proves its value as a normative guide in work design and redesign, since it simultaneously aims at efficiency improvement as well as at humanisation. (...) This is laid down into the approach of complete vs. partial tasks and activities. (...) Activities can be considered to be sequentially complete when they do not merely allow people to execute the task, but also allow them to do the required preparatory cognitive operations (in particular goal setting and deciding on the measures to be taken). These cognitive operations are particularly necessary when people participate in organising the work, and checking the results of one's work. Moreover a task is considered to be hierarchically complete, when the mental regulation is not limited to automated processes, but requires controlled, i.e., knowledge-based and, moreover, intellectual control processes as well. Sequentially and hierarchically complete activities offer the crucial option of learning, as opposed to deterioration skills and abilities in simple and limited routine activities. Decision latitude (or autonomy) is the most important feature of complete activities. Complete activities offer the decision latitude that is necessary for setting one's goals. These are prerequisites of comprehensive cognitive requirements of a task, and determine the intrinsic task motivation, i.e., being motivated by a challenging job. These aspects serve as a well-known buffer against negative consequences of high workload" [Hacker, (2003), p.112].

De Sitter (1981) integrated the 'job demands-control-model' (Karasek, 1979) in his theory. The job demands-control (JDC)-model holds two predictions. High job demand and low job control separately represent risk factors that are detrimental to (mental) health outcomes such as work stress and coronary heart disease. The model also predicts that high job demand, as well as high job control fosters motivation and learning. The most commonly used definition of job control (or decision latitude) - which describes the features of jobs and not of individual job performers - is primarily the ability of the worker to use his or her skills on the job and to have authority to make decisions regarding how the work is done, and to set the schedule for completing work activities. Central features of the JDC-model are also the strain and learning hypotheses, referring to two interaction hypotheses on the balance between job demands and job control. Jobs with high demands and low control can be called 'high strain jobs' which are a risk for work-related stress. Moreover, stress inhibits learning. But jobs with high demands as well as high control are called 'active jobs' which offer opportunities for learning and coping with stressors (Karasek, 1979; Karasek and Theorell, 1990). Later, this JDCmodel was extended with the social support dimension (support of colleagues and supervisor) and with innovative and productive work behaviour (Karasek and Theorell, 1990). There is empirical evidence for the JDC-model. Reviews of longitudinal studies lend support to these strain and learning interaction hypotheses (De Lange et al., 2003, 2005; Taris et al., 2003). The main effects of job demands and job control on health and well-being are more often found than demands-control-interaction effects (Häusser et al., 2010). However, empirical findings with the model also suggest that especially the presence of high job demands, more than a lack of job control, results in work stress and work-related health problems. Conversely, especially the presence of job control is associated with positive outcomes, such as learning, job engagement, well-being and organisational commitment (Demerouti et al., 2001; cf., Taris et al., 2003; Lyness et al., 
2012; Stansfeld et al., 2013; Gallie, 2013; Dhondt et al., 2014). Although these correlations have been investigated more frequently than other correlations job design and team working cover only part of the reality because a systemic view of the whole organisation is needed - hence the inclusion of all aspects of the First and Second Elements. Only then these outcomes represent a convergence between improved economic performance for the firm and improved quality of working life.

It goes without saying that work organisation and technical systems should be geared to each other. These days in the Netherlands (mid 2015) an official Parliamentary Inquiry is going on to find out why so many ICT-projects of government agencies turned out to be a disaster, practically as well as financially. Probably these dramas occur in private businesses as well. Moreover front office workers, for instance in banking and in call centres get stressed and experience (part of) the ICT as a hindrance to serve clients properly because of the structure of the formats and the decision rules in the software. From a sociotechnical point of view (De Sitter, 1994) it is clear what went wrong. Digitalisation and automation were implemented before optimising processes and work organisation. End users were not involved sufficiently. In their book 'The second machine age' Brynjolfsson and McAfee (2014) of MIT observe that in big companies with big ICT projects it takes five to seven years before the organisation has been redesigned and consequently before full benefits can be taken from the new technology. They say "Creativity and organizational redesign is crucial to investments in digital technologies" (p.138). Their concept is 'co-invention of organisation and technology'. This co-invention requires the creativity and collaboration on the part of the entrepreneurs, managers and workers. There can be no effective and sustainable returns on automation and digitalisation without workplace innovation.

\subsection{The third element: learning, reflection and innovation}

The proportional shift from tangible to intangible investments meant a lot for styles of management. As 'hard' technological innovations do not seem to explain persistent productivity differentials, Bloom and Van Reenen (2010) present evidence on another possible explanation for persistent differences in productivity at the firm and the national level - namely, that such differences largely reflect variations in management practices. They stand in the tradition of the resource-based view of the organisation as the framework of research into the conditions for acquiring and maintaining competitive advantage. The focus is not only on the competitiveness of products and services but on internal resources for competitive advantage as well, such as management skills, work organisation, knowledge and competences. Competitive advantage can be achieved when these resources improve efficiency and efficacy and when they are rare or difficult to copy. The dynamic resource-based view of today, taking into account necessary adaptations to changes in the environment is directed at dynamic capabilities (Eisenhardt and Martin, 2000). The OECD calls it 'knowledge-based capital' (KBC) (OECD, 2012). So, this is not only about management capabilities but about innovation capabilities on organisational level as well. One of these management capabilities is 'managing human resources', how to stimulate 'employee voice' or develop 'employee capabilities'.

In the learning theory by Argyris and Schön (1978) two levels of control can be recognised. "Ordinary repetitive acting corresponds with the 'given order with prescribed procedures' method. Innovative acting includes the characteristics of ordinary repetitive 
acting, but is also aiming for improvement of procedures, working conditions, and results in order to enhance effectiveness or efficiency" [Argyris and Schön, (1978), p.117]. The theories of the first and second elements (STSD; job demands - control-model; complete jobs) can be related to this learning theory. Job autonomy (internal control capacity) relates to 'single loop learning' (doing things better) and complex or complete jobs with external control capacity facilitate 'double loop learning' (e.g., 'are we doing the right things?'). Another way of conceptualising learning on the organisational level is the use of the concept of 'productive reflection', covering jointly "the role that organisational structures have in articulating employee voice together with the active use of employee's formal and tacit skills and competences in the process of improvement, innovation and change" [Cressey et al., (2013), p.221].

Action-researchers stress that the design approach, which emphasises the expert-led introduction of prescribed organisational forms, has emerged as a roadblock rather than a motor for real change in organisations. Generalisable knowledge needs to be reinvented in the form of 'local theories' grounded in dialogue, cultural identity and organisational context (Fricke, 1997; Gustavsen, 1992). It is not sufficient to produce 'star' cases in the hope that wider diffusion will follow. All stakeholders have to be involved. Agencies with capacity for dissemination such as chambers of commerce, social partners and universities need to be active participants in programs and initiatives, and transferable lessons can be fed through inter-organisational learning networks.

\subsection{The fourth element: workplace partnership}

However, job control is not a sufficient condition and productive reflection is not only a matter of good intentions. Nobel-prize winner Akerlof (1982) contends from an economic perspective that participation needs to take the form of gift-exchange or reciprocity to be effective. Gustavsen (1992) emphasises the need for democratic relations to optimise the outcomes for management and employees alike. Workplace partnership is also about dealing with power relations and different interests. That is why employers' associations and trade unions as well as government agencies are involved in most workplace innovation initiatives and programs (Totterdill et al., 2009; Pot et al., 2012b). Sometimes the government is leading (e.g., Finland, Germany), sometimes the social partners are leading (e.g., UK, Netherlands). As we know from Naschold's (1994) 'best practice model' for national workplace development, the strategic justification should primarily arise from macro-level industrial policy issues rather than the industrial relations system or the research and development system alone. The most sustainable innovation can be achieved if companies, social partners, governments and research organisations work together.

\subsection{The fifth element: integrated approach and alchemy}

The sociotechnical design theory is a system's approach, integrating technological and social innovation. For the foundation of explanatory theories and design theories it can be related to the 'configurational approach of strategic human resource management' (SHRM). "In general, configurational theories are concerned with how the pattern of multiple independent variables is related to a dependent variable rather than with how individual independent variables are related to the dependent variable" [Delery and Doty, (1996), p.804]. From a design point of view this means that 'HR-bundles' are more 
effective than separate interventions (Sheehan, 2013). In EUWIN-terminology we would say: integrating the four elements, the alchemy, is creating the fifth element.

\section{Discussion and perspectives}

Regarding work organisation the European Commission has been developing bits and pieces of policy since about 1995. Although it was always to achieve higher productivity, more innovation capability, more employment and better jobs simultaneously, the emphasis in the nineties was on productivity, in the beginning of this century on employment and the last ten years on innovation. The message that organisational performance and quality of working life are two sides of the same coin came primarily from the network of 'occupational safety, health and well-being'.

In the lobbying for and development of these policies an important role has always been played by researchers and their networks. Policies were developed bottom-up by coalitions of European Commission officials and researchers who organised seminars, etc., to convince the Commission's directors, directors-general and finally commissioners. Sometimes also a few representatives of trade unions and/or employers' associations were active in these networks. These coalitions have appeared to be successful.

Policies on work organisation and workplace innovation have remained fragmented. The 'workplace innovation people' refer to productivity, innovation, competitiveness and employment, but the 'productivity people', the 'innovation people', the 'competitiveness' people and the 'employment people' hardly refer to workplace innovation, with some exceptions. However, there is some progress. The policies of DG GROW and DG EMPL clearly overlap and more contacts between the two are being planned. It is helpful that there is agreement on the use of the concept of workplace innovation as using different concepts makes it very difficult to develop policies and common understanding.

The financial and economic crises did not seem to have much influence on the attention for workplace innovation. Important steps in EU-policy were put during the crisis as well as in some countries. To give some examples: in the Netherlands the general employers' association (AWVN) advocated in 2009 that because of the crisis workplace innovation had become even more urgent. In Ireland, the tripartite program on workplace innovation had ended according to plan just before the crisis, but the unions, in particular Services, Industrial, Professional and Technical Union (SIPTU), continued to organise seminars and develop projects. Finland and Germany renewed their programs during the crises as they did for decades and Belgium started the 'Flanders Synergy' program on workplace innovation in 2009. Nevertheless increased competition as a consequence of crisis and globalisation lures opposite reactions like cost cutting and a stronger command-and-control style of leadership, sometimes called 'the low road' (Totterdill et al., 2002). This is more likely to happen in organisations and countries which are not yet familiar with ideas and examples of workplace innovation. The 'high road' is to welcome globalisation as a challenge for competence development and more job control.

This is also understood by some agencies in the 'new member states'. The idea of workplace innovation is nowadays actively been disseminated in those countries, sometimes supported by the EUWIN, sometimes by national programs such as the 
Finnish (Makó et al., 2015). Like in Western European countries researchers play an important role in disseminating the innovative ideas.

Policies of work organisation and workplace innovation have never resulted into legislation or regulations on EU-level. Mentioning the issues in Employment Guidelines did not seem to help much nor did national legislation in a few countries. Probably workplace innovation is not suitable for a legislative approach. Implementation depends very much on the social dialogue at European, national, sectoral and organisation level. But EU- and national-authorities can stimulate that dialogue and develop campaigns for knowledge dissemination and capacity building. Some of them do, but unfortunately for a short period of time. Germany and Finland are the exceptions with programs that have been renewed several times over the past decades.

For a number of reasons many enterprises, hospitals, government departments, etc., do not implement workplace innovation as a matter of course, in spite of the obvious benefits for employees and employers. That is why a better coordinated policy and more action is needed by governments, social partners and research institutes.

There is room for improvement. In the European Working Conditions Survey of 2010 one question was: "Are you involved in improving the work organisation or work processes of the department or organisation?" Of the responding employees in the EU-27 countries 46.7\% answered 'always' or 'most of the time' (Eurofound, 2012).

Part of that policy should be research into the obstacles and mechanisms that contribute to not implementing workplace innovation as a matter of course and into the mechanisms that support implementation. A couple of countries have experiences with national campaigns but so far there is little evaluation research available.

Entrepreneurs do not have to wait for these policies. There is enough evidence that workplace innovation leads to enhanced organisational performance and better jobs. Facing dilemmas either 'operational excellence versus innovation', or 'short-term results versus long-term competitiveness', or 'demand and control versus participation and trust', the better choice to deal with these dilemmas is always workplace innovation. Maybe the 'fifth element approach' looks rather complicated, but it starts easily by asking the front line employees and their supervisors how their work could be organised better. Try it and you will be surprised.

\section{References}

Akerlof, G.A. (1982) 'Labor contracts as partial gift exchange', Quarterly Journal of Economics, Vol. 97, No. 4, pp.543-569.

Alasoini, T., Ramstad, E., Hanhike, T. and Lahtonen, M. (2005) European Programmes on Work and Labour Innovation - A Benchmarking Approach, Work-In-Net, Helsinki/Bonn.

Andreasen, L.E., Coriat, B., den Hertog, J.F. and Kaplinsky, R. (1995) Europe's Next Step: Organisational Innovation, Competition and Employment, Frank Cass, Ilford.

Argyris, C. and Schön, D. (1978) Organizational Learning, Addison-Wesley, Massachusetts.

Bloom, N. and Van Reenen, J. (2010) 'Why do management practices differ across firms and countries?', Journal of Economic Perspectives, Vol. 24, No. 1, pp.203-224.

Bolwijn, P.T., van Breukelen, Q.H., Brinkman, S. and Kumpe, T. (1986) Flexible Manufacturing: Integrating Technological and Social Innovation, Elsevier, Amsterdam.

Brödner, P. and Latniak, E. (2002) Sources of Innovation and Competitiveness: National Programmes Supporting the Development of Work Organisation, Report to DG Employment and Social Affairs, Institute for Work and Technology, Gelsenkirchen. 
Brynjolfsson, E. and McAfee, A. (2014) The Second Machine Age: Work, Progress, and Prosperity in a Time of Brilliant Technologies, W.W. Norton, New York/London.

Corrado, C. and Hulten, C. (2010) 'How do you measure a technological revolution?', American Economic Review, Vol. 100, No 5, pp.99-104.

Cressey, P., Totterdill, P. and Exton, R. (2013) 'Workplace social dialogue as a form of 'productive reflection", International Journal of Action Research, Vol. 9, No. 2, pp.209-245.

De Lange, A.H., Taris, T.W., Kompier, M.A.J., Houtman, I.L.D. and Bongers, P.M. (2003) 'The very best of the millennium: longitudinal research and the demand-control-(support) model', Journal of Occupational Health Psychology, Vol. 8, No. 4, pp.282-305.

De Lange, A.H., Taris, T.W., Kompier, M.A.J., Houtman, I.L.D. and Bongers, P.M. (2005) 'Different mechanisms to explain the reversed effects of mental health on work characteristics', Scandinavian Journal of Work, Environment and Health, Vol. 31, No. 5, pp.3-14.

De Sitter, L.U. (1981) Op weg naar nieuwe fabrieken en kantoren (Translated: Heading for New Factories and Offices), in Dutch, Kluwer, Deventer.

De Sitter, L.U. (1994) Synergetisch produceren. Human Resources Mobilisation in de produktie: een inleiding in de structuurbouw, Van Gorcum, Assen.

De Sitter, L.U., den Hertog, J.F. and Dankbaar, B. (1997) 'From complex organizations with simple jobs to simple organizations with complex jobs', Human Relations, Vol. 50, No. 5 , pp.497-534.

Delery, J.E. and Doty, D.H. (1996) 'Modes of theorizing in strategic human resources management: tests of universalistic, contingency, and configurational performance predictions', The Academy of Management Journal, Vol. 39, No. 4, pp.802-835.

Demerouti, E., Bakker, A.B., Nachreiner, F. and Schaufeli, W.B. (2001) 'The job demands-resources model of burnout', Journal of Applied Psychology, Vol. 86, No. 3, pp.499-512.

Dhondt, S., Pot, F. and Kraan, K. (2014) 'The importance of organizational level decision latitude for wellbeing and organizational commitment', Team Performance Management: An International Journal, Vol. 20, Nos. 7/8, pp.307-327.

Dhondt, S., van Gramberen, M., Keuken, F., Pot, F., Totterdill, P. and Vaas, F. (2011) Workplace Innovation, Social Innovation Europe Launch Event, Brussels, UKWON, Nottingham [online] http://portal.ukwon.eu/document-store/social-innovation-europe-lauch-event-why-isworkplace-innovation-a-key-dimension-of-social-innovatio (accessed 13 August 2015).

Docherty, P., Forslin, J. and Dhani, A.B. (Eds.) (2002) Creating Sustainable Work Systems: Emerging Perspectives and Practice, Routledge, London/New York.

Dortmund-Brussels Declaration (2012) [online] http://portal.ukwon.eu/document-store/dortmundbrussels-position-summary-workplace-innovation-as-social-innovation (accessed 13 August 2015).

EANPC (2005) Productivity, the High Road to Wealth, European Association of National Productivity Centres, Brussels.

Eeckelaert, L., Dhondt, S., Oeij, P., Pot, F., Nicolescu, G.I., Webster, J. and Elsler, D. (2012) Review of Workplace Innovation and Its Relation with Occupational Safety and Health, European Agency for Safety and Health at Work, Bilbao.

EESC (2011) Opinion of the European Economic and Social Committee on Innovative Work Places as a Source of Productivity and Quality Jobs [online] http://www.eesc.europa.eu/resources/docs/ces543-2011_ac_en.doc (accessed 9 November 2012).

Eisenhardt, K.M. and Martin, J.A. (2000) 'Dynamic capabilities: what are they?', Strategic Management Journal, Vol. 21, Nos. 10-11, pp.1105-1121. 
Ennals, R. (1998) 'Partnership for a new organisation of work and Europe as a development coalition: an interview with Allan Larsson, Director-General of DG-V, European Commission', Concepts and Transformation, Vol. 3, Nos. 1-2, pp.143-152.

Ennals, R., Totterdill, P. and Ford, C. (2004) 'A national coalition for working', in Fricke, W. and Totterdill, P. (Eds.): Action Research in Workplace Innovation and Regional Development, pp.331-336, John Benjamins Publishing, Amsterdam.

Eurofound (2012) Fifth European Working Conditions Survey, Publications Office of the European Union, Luxembourg.

Eurofound (2013) Third European Company Survey: First Findings, Dublin.

European Agency for Safety and Health at Work (EU-OSHA) (2013a) Priorities for Occupational Safety and Health Research in Europe: 2013-2020, EU OSHA, Bilbao.

European Agency for Safety and Health at Work (EU-OSHA) (2013b) Well-being at Work Creating a Positive Work Environment, EU OSHA, Bilbao.

European Commission (2003) Council Decision of 22nd July 2003 on Guidelines for the Employment Policies of the Member States, OJEC, 5.8.2003, L 197/13, para 14.

European Commission (2010a) Europe 2020: A strategy for smart, sustainable and inclusive growth, $\operatorname{COM(2010)} 2020$ final, 3 March 2010, Brussels.

European Commission (2010b) Proposal for a Council Decision on Guidelines for the Employment Policies of the Member States: Part II of the Europe 2020 Integrated Guidelines, COM92010 $193 / 3$, Brussels.

European Commission (2014) Advancing Manufacturing - Advancing Europe - Report of the Task Force on Advanced Manufacturing for Clean Production, SWD(2014) 120 final, Commission staff working document, Brussels.

European Commission (2015) Employment and Social Developments in Europe 2014, Brussels.

European Foundation for the Improvement of Living and Working Conditions (Eurofound) (1997) Employee Participation and Organisational Change: EPOC Survey of 6000 Workplaces in Europe, European Foundation, Dublin.

European Parliament (2013) Report on Reindustrializing Europe to Promote Competitiveness and Sustainability, 2013/2006(INI).

European Work \& Technology Consortium (1998) A Medium Term Plan for Collaborative Action, Centre for Work \& Technology, Nottingham.

EWON (2002) The Use of ESF Funds in Supporting the Modernisation of Work Organisation, Unpublished report for the European Commission [online] http://uk.ukwon.eu/File\%20Storage/5032375_7_EC-Work-Organisation-ESF-FinalReport.pdf (accessed 13 August 2015).

Fricke, W. (1997) 'Evaluation of the German work and technology programme from an action research point of view', in Alasoini, T., Kyllönen, M. and Kasvio, A. (Eds.): Workplace Innovation: A Way of Promoting Competitiveness, Welfare and Employment, National Workplace Development Programme, Helsinki.

Gallie, D. (2013) 'Direct participation and the quality of work', Human Relations, Vol. 66, No. 4, pp.453-473.

Gittell, J.H., Seidner, R. and Wimbush, J. (2010) 'A relational model of how high performance work systems work’, Organization Science, Vol. 21, No. 2, pp.490-506.

Grootings, P., Gustavsen, B. and Héthy, L. (Eds.) (1991) New Forms of Work Organization, Transaction Publishers, New Brunswick, New Jersey.

Gustavsen, B. (1992) Dialogue and Development: Theory of Communication, Action Research and the Restructuring of Working Life, Van Gorcum, Assen.

Hacker, W. (2003) 'Action regulation theory: a practical tool for the design of modern work', European Journal of Work and Organizational Psychology, Vol. 12, No. 2, pp.105-130. 
Häusser, J.A., Mojzisch, A., Niesel, M. and Schulz-Hardt, S. (2010) 'Ten years on: a review of recent research on the job demand-control (-support) model and psychological well-being', Work \& Stress, Vol. 24, No. 1, pp.1-35.

Høyrup, S., Bonnafous-Boucher, M., Hasse, C., Lotz, M. and Møller, K. (Eds.) (2012) Employee-Driven Innovation: A New Approach, Palgrave Macmillan, London.

IndustriAll European Trade Union (2014) Manifesto to Put Industry Back to Work, Brussels.

Ioannou, C.A. (2006) 'Why is modern work organisation lacking from Southern European public policies? The case of Greece', The International Journal of Comparative Labour Law and Industrial Relations, Vol. 22, No. 1, pp.19-37.

Karasek, R.A. (1979) 'Job demands, job decision latitude, and mental strain: implications for job redesign', Administrative Science Quarterly, Vol. 24, No. 2, pp.285-308.

Karasek, R.A. and Theorell, T. (1990) Healthy Work; Stress, Productivity and the Reconstruction of Working Life, Basic Books, New York.

Kesselring, A., Blasy, C. and Scoppetta, A. (2014) Workplace Innovation: Concepts and Indicators, European Commission, Brussels.

Lyness, K.S., Gornick, J.C., Stone, P. and Grotto, A.R. (2012) 'It's all about control: worker control over schedule and hours in cross-national context', American Sociological Review, Vol. 77, No. 6, pp.1023-1049.

Makó, C., Illéssy, M., Csizmadia, P. and Balázs, H. (2015) 'Mapping the context for transfer of Finnish workplace development practice: the case of Finland, Hungary and Romania', Journal of Self-Governance and Management Economics, Vol. 3, No. 2, pp.7-29.

Mohr, B. and Van Amelsvoort, P. (Eds.) (2015) Co-creating Humane and Innovative Communities of Work: The Evolution of STS Design Practice and Perspective, to be published in September 2015.

Naschold, F. (1994) 'The politics and economics of workplace development', in Kauppinen, T. and Lahtonen, M. (Eds.): National Action Research Programmes in the 1990s, (Labour Policy Studies 86), Ministry of Labour, Helsinki, pp.109-155.

OECD (2010a) The OECD Innovation Strategy: Getting a Head Start on Tomorrow, OECD, Paris [online] http://www.oecd.org/sti/45326349.pdf (accessed 13 August 2015).

OECD (2010b) Innovative Workplaces: Making Better Use of Skills Within Organizations, OECD, Paris [online]

http://www.oecd.org/sti/inno/innovativeworkplacesmakingbetteruseofskillswithinorganisation s.htm (accessed 13 August 2015).

OECD (2012) New Sources of Growth, Knowledge-Based Capital Driving Investment and Productivity in the 21st Century, OECD, Paris.

Oeij, P., Žiauberytė-Jakštienè, R., Dhondt, S., Corral, A., Totterdill, P. and Preenen, P. (2015) Workplace Innovation in European Companies, Eurofound, Dublin.

Pot, F., Dhondt, S. and Oeij, P. (2012a) 'Social innovation of work and employment', in Franz, H-W., Hochgerner, J. and Howaldt, J. (Eds.): Challenge Social Innovation: Potential for Business, Social Entrepreneurship, Welfare and Civil Society, pp.261-274, Springer, Berlin.

Pot, F., Dhondt, S., de Korte, E., Oeij, P. and Vaas, F. (2012b) 'Workplace innovation in the Netherlands', in Houtman, I. (Ed.): Work Life in the Netherlands, TNO Work and Employment, pp.173-190, Hoofddorp.

Pot, F.D. (2011) 'Workplace innovation for better jobs and performance', International Journal of Productivity and Performance Management, Vol. 64, No. 4, pp.405-415.

Ramstad, E. (2009) 'Promoting performance and the quality of working life simultaneously', Internal. Journal of Productivity and Performance Management, Vol. 58, No. 5, pp.423-436.

Sandberg, A. (Ed.) (2013) Nordic Lights: Work, Management and Welfare in Scandinavia, SNS FÖRLAG, Stockholm. 
Savage, P. (Ed.) (2001) 'New forms of work organisation: the benefits and impact on performance', Thematic paper presented to DG Employment and Social Affairs, European Work Organisation Network (EWON), Nottingham.

Sheehan, M. (2013) 'Human resource management and performance: evidence from small and medium-sized firms', International Small Business Journal, published online 6 January, doi: 10.1177/0266242612465454.

Stansfeld, S.A., Shipley, M.J., Head, J., Fuhrer, R. and Kivimäki, M. (2013) 'Work characteristics and personal social support as determinants of subjective well-being', PLoS ONE, Vol. 8, No. 11, p.e81115, doi:10.1371/journal.pone.0081115.

Taris, T.W., Kompier, M.J., De Lange, A.H., Schaufeli, W.B. and Schreurs, P.J.G. (2003) 'Learning new behaviour: a longitudinal test of Karasek's active learning hypothesis among Dutch teachers', Work \& Stress, Vol. 17, No. 1, pp.1-20.

Totterdill, P. (2003) 'Europe's advantage? Work organisation, innovation and employment', in Cowling, K. (Ed.): Industrial Policy in Europe: Theoretical Perspectives and Practical Proposals, pp.74-87, Routledge, Oxford.

Totterdill, P. (2010) Workplace Innovation: Europe 2020's Missing Dimension, Report of a workshop hosted by DG Employment, Social Affairs and Equal Opportunities, 23 June, UKWON, Nottingham.

Totterdill, P. (2013) Workplace Innovation: The Fifth Element, EUWIN, Nottingham [online] http://portal.ukwon.eu/the-fifth-element-new (accessed 13 August 2015).

Totterdill, P., Exton, R., Exton, O. and Gold, M. (2012a) 'Closing the gap between evidence-based and common practice. Workplace innovation and public policy in Europe', Lifelong Learning in Europe (LLinE), No. 4 [online] http://www.lline.fi/en/article/policy/totterdill/closing-thegap-between-evidence-based-and-common-practice-workplace-innovation-and-public-policyin-europe\#title14 (accessed 13 August 2015).

Totterdill, P., Cressey, P. and Exton, R. (2012b) 'Social innovation at work: workplace innovation as a social process', in Franz, H-W., Hochgerner, J. and Howaldt, J. (Eds.): Challenge Social Innovation: Potential for Business, Social Entrepreneurship, Welfare and Civil Society, pp.241-260, Springer, Berlin.

Totterdill, P., Dhondt, S. and Milsome, S. (2002) Partners at Work? A Report to Europe's Policy Makers and Social Partners, The Work Institute, Nottingham [online] http://portal.ukwon.eu/document-store/partners-at-work (accessed 13 August 2015).

Totterdill, P., Exton, O., Exton, R. and Sherrin, J. (2009) Workplace Innovation Policies in European Countries, UKWON, Nottingham.

Volpert, W., Kötter, W., Gohde, H-E. and Weber, W.G. (1989) 'Psychological evaluation and design of work tasks: two examples', Ergonomics, Vol. 32, No. 7, pp.881-890.

Work-In-Net (WIN) (2010) The Grand Societal Challenge: Sustainable European Work to Withstand Global Economic Change and Crisis, Declaration 11-12 March, WIN, Berlin. 